\title{
Characterization of Salmonella Enteritidis isolated from foods and patients in northern Morocco
}

\author{
Sanae Ammari ${ }^{1,2}$, Amin Laglaoui ${ }^{2}$, Latifa En-nanei ${ }^{1}$, Sophie Bertrand ${ }^{3}$, Christa Wildemauwe ${ }^{4}$, \\ Said Barrijal ${ }^{2}$, Mohammed Abid ${ }^{1}$ \\ ${ }^{1}$ Service de recherche, Laboratoire de biologie moléculaire, Institut Pasteur du Maroc, Tanger, Maroc \\ ${ }^{2}$ Equipe de Recherche sur la Valorisation Biotechnologique des Microorganisme ERVABIM, Faculté des Sciences et \\ Techniques, B.P. 416, Tanger, Maroc \\ ${ }^{3}$ Bacteriology Division, Scientific Institute of Public Health, J. Wytsman Street, 14 B-1050, Brusels, Belgium \\ ${ }^{4}$ Pasteur Institute, Phage typing service, Engelandstreet 642- B-1180, Brussels, Belgium
}

\begin{abstract}
Objectives: This study aimed to investigate Salmonella Enteritidis strains isolated from human and food sources in the north of Morocco by means of phenotypic and genotypic methods.

Methodology: Fifteen isolates from humans and food were submitted to phage typing, XbaI-macrorestriction (pulsed field gel electrophoresis [PFGE]), enterobacterial repetitive intergenic consensus (ERIC-PCR), antimicrobial susceptibility testing, and PCR assay targeting the $s p v R$ and invA genes.

Results: Six fingerprinting profiles were obtained with the ERIC-PCR method, four with PFGE profiling, five with antimicrobial resistance, three with phage typing, and only one with plasmid profiling. $s p v R$ gene was detected in six strains, which did not harbour plasmids of $90 \mathrm{~kb}$. Conclusions: The conclusions of this study are drawn from a limited number of isolates. It would be desirable to investigate a greater and more diverse population of Salmonella isolates. S. Enteritidis was genotyped and showed four different patterns by PFGE and six by ERICPCR. Accordingly, high genetic similarity and limited genetic diversity were found for these strains from north of Morocco.
\end{abstract}

Key words: Salmonella Enteritidis, ERIC-PCR, phage typing, PFGE, plasmid, antimicrobial resistance

J Infect Dev Ctries 2009; 3(9):695-703.

Received 17 October 2008 - Accepted 12 August 2009

Copyright (C) 2009 Ammari et al. This is an-open access article distributed under the Creative Commons Attribution License, which permits unrestricted use, distribution, and reproduction in any medium, provided the original work is properly cited.

\section{Introduction}

Salmonella Enteritidis is widely recognized as a major cause of food-borne gastroenteritis in humans and has been isolated from cases of human diseases in increasing numbers worldwide [1]. Animals and their products, particularly chicken, meat and eggs, are considered to be major sources of human infections caused by this pathogen [2].

Prior to 1988, Salmonella enterica ser. Typhimirium was more commonly isolated than Salmonella Enteritidis; however, in recent years, $S$. Enteritidis has been the most common serotype isolated from food and has been particularly responsible for the overall increase in Salmonella infections in humans [3].

The investigation of phenotypic and molecular profiles can provide the epidemiological characterization of Salmonella strains, and can help elucidate their cycle of transmission [4]. However, to achieve a higher confidence level on the results, epidemiological tracing should be based on the association of independent genotypic and phenotypic characteristics [5].

Phage typing and antimicrobial resistance profiles are phenotypic properties that have been used worldwide [6], usually in association with a number of nucleic acid-based typing methods that have been proposed for typing bacteria [5]. Another approach is the analysis of fragment patterns obtained by macrorestriction and separated using the pulsed field gel electrophoresis (PFGE) technique. Since its development, PFGE has become the method of choice to determine the relationship of Salmonella strains and to assess the distribution of clonal strains. Very recently, the use of PFGE with endonuclease $\mathrm{XbaI}$ has been widely recognized as a sensitive means of fingerprinting Salmonella serovars and has become a reference method [4].

However, more information can be gathered by analyzing plasmids from the isolates or chromosomal 
DNA by different molecular techniques, such as ERIC (enterobacterial repetitive intergenic consensus), REP (repetitive extragenic palindromic), random amplified polymorphic DNA analysis (RAPD), IS 200 typing and ribotyping, and restriction fragment length polymorphism (RFLP) [7]. Among the molecular methods for typing bacteria, the ERIC genomic fingerprinting has been found to be extremely reliable, reproducible, and rapid; furthermore, it offers high discrimination [8].

The virulence properties of various serovars, $S$. Typhimurium, $S$. Choleraesuis, $S$. Dublin, and $S$. Enteritidis, depend on the presence of large plasmids $65-100 \mathrm{~kb}$ in size to cause systemic infection [9]. The virulence of Salmonella is linked to a combination of chromosomal and plasmid factors. The chromosomally located invasion gene invA has been thought to trigger the invasion of Salmonella into cultured epithelial cells, while an operon $s p v R A B C D$, containing five genes, is present on plasmids. The $s p v$ operon ( $s p v$ ABCDR) is involved in resistance to macrophage damage and is considered important for the virulence of Salmonella. Furthermore, the $s p v R$ gene has been targeted in PCR assays in order to characterize Salmonella strains [10].

In Morocco, an epidemiological study of Salmonella in Rabat between 1990 and 1997 showed an important increase of isolated cases since 1994 with maximum case detection in 1996. The prevalent serotypes identified were $S$. Enteritidis, which represented $(56.54 \%)$ of the total of the isolated strains [11]. The rise of $S$. Enteritidis infections was linked to the explosion of food-related outbreaks. The most predominant serotypes detected in Morocco, as in most developed countries, were $S$. Enteritidis and $S$. Typhimirium [12]. The serotypes isolated in a university hospital in Casablanca between 1994 and 2002 were $S$. Typhumurium (53.6\%), S. Enteritidis (44\%) and S. Agona (2.4\%) [13].

In the present study, we examined strains of Salmonella Enteritidis isolated from patients with acute diarrhoea and from food collected and received for diagnosis in the Pasteur Laboratory for their phenotypic and genetic diversity.

\section{Materials and Methods}

Specimen collection and isolation of $S$. Enteritidis

A total of 100 diarrhoeal samples were collected from patients attending the five medical centres and one regional hospital involved in this study and recruited in the Pasteur Institute of Morocco. The 100 clinical isolates were from the faeces of patients with sporadic cases of gastroenteritis admitted to the various hospitals. Most of the patients were of low or middle socioeconomic status. The samples were collected between February 2005 and August 2006. All samples were inoculated into Selenite broth and on Salmonella-Shigella (SS) and Hektoen agars. Hektoen and SS were incubated at $37^{\circ} \mathrm{C}$ for 18 to 24 hours, and Selenite broth at $37^{\circ} \mathrm{C}$ for 12 to 18 hours. After incubation, Selenite broth was inoculated in SS agar and Hektoen at $37^{\circ} \mathrm{C}$ for 18 to 24 hours [14].

In addition, food samples collected from many markets in the region of Tangier were analyzed. A total of 432 samples were aseptically collected on a random basis from different localities (different markets) in north Morocco. All the samples were placed in sterile plastic bags and immediately taken in a container containing ice cubes to the laboratory for bacteriological analysis.

Approximately $25 \mathrm{~g}$ of food was placed in $225 \mathrm{ml}$ of Buffered Peptone Water (BPW) as pre-enrichment media, and incubated at $37^{\circ} \mathrm{C}$ for 18 hours. After incubation, $0.1 \mathrm{ml}$ of the BPW was added to Rappaport-Vasiliadis broth, an enrichment media, and incubated at $42^{\circ} \mathrm{C}$ for 18 hours. A swab of the broth was inoculated onto Hektoen selective media [15].

Suspected colonies of Salmonella were inoculated in Urea Indole at $37^{\circ} \mathrm{C}$ for 2 to 4 hours, in Hajna Kligler at $37^{\circ} \mathrm{C}$ for 18 to 24 hours, and in ONPG disc for biochemical testing and presumptive identification. All isolates were identified biochemically by using the API20 E system (Biomerieux SA, Marcy-l'Etoile France).

\section{Serotyping and phage typing}

Strains were serotyped following the method of Kauffman [15] with commercial antisera (Biomerieux SA, France) for cell wall (O) and flagellar $(\mathrm{H})$ antigen identification, and were confirmed at the Pasteur Institute, Bruxel, Belgium.

Phage typing was performed according to the recommendations of the Health Protection Agency Service (Colindale, UK) (16) in the Pasteur Institute, Brussels, Belgium.

\section{Determination of Antimicrobial drug resistance}

Antimicrobial susceptibility of the isolates was established by the disk diffusion assay with $\mathrm{MH}$ (Mueller-Hinton) agar in accordance with French National Antibiogram committee guidelines [10]. The 
Table 1. General percentages of antimicrobial resistance among $S$. Enteritidis isolated from humans and food

\begin{tabular}{|c|c|c|c|}
\hline & \multicolumn{3}{|c|}{ Antimicrobial resistance (\%) } \\
\hline Antibiotics & Sensitive & Intermediate & Resistant \\
\hline AMX & 86.66 & 0 & 13.34 \\
\hline $\mathbf{F}$ & 79.99 & 6.67 & 13.34 \\
\hline TIC & 86.66 & 0 & 13.34 \\
\hline CEF & 100 & 0 & 0 \\
\hline GEN & 93.33 & 0 & 6.67 \\
\hline TOB & 100 & 0 & 0 \\
\hline NAL & 93.33 & 0 & 6.67 \\
\hline NOR & 100 & 0 & 0 \\
\hline CIP & 100 & 0 & 0 \\
\hline CAZ & 100 & 0 & 0 \\
\hline AMC & 100 & 0 & 0 \\
\hline AMK & 100 & 0 & 0 \\
\hline FOX & 100 & 0 & 0 \\
\hline CTX & 100 & 0 & 0 \\
\hline AMP & 86.66 & 0 & 13.34 \\
\hline
\end{tabular}

disks used contained: amoxicillin, AMX $25 \mu \mathrm{g}$; furan, F $30 \mu \mathrm{g}$; ticarcillin, TIC $75 \mu \mathrm{g}$; cephalothin, CEF 30 $\mu \mathrm{g}$; gentamicin, GEN $15 \mu \mathrm{g}$; tobramycin, TOB $10 \mu \mathrm{g}$; nalidixicacid, NAL $30 \mu \mathrm{g}$; norfloxacin, NOR $5 \mu \mathrm{g}$;

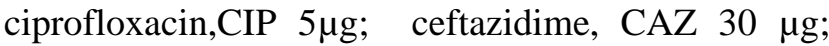
amoxicillin-clavulanic acid, AMC 20+10 $\mu \mathrm{g}$; amikacin, AMK $30 \mu \mathrm{g}$; cefoxitin, FOX $30 \mu \mathrm{g}$;

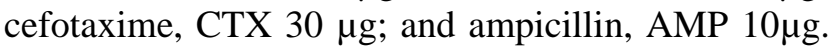
We used the Automated System (OSIRIS) for Reading and Interpreting results (Bio-Rad).

\section{Macrorestriction analysis (PFGE)}

Genomic DNA suitable for pulsed-field gel electrophoresis (PFGE) was prepared according to the PulseNet method (www.cdc.gov/pulsenet) and digested with the restriction endonuclease $\mathrm{XbaI}$ (New-England Biolab, Leudsen, Netherlands). Salmonella enterica serovar Braenderup H9812 was used as a size marker. Fingerprinting II (Informatix ${ }^{\mathrm{TM}}$ Software) (Bio-Rad) was used to compare the PFGE profiles [17]. The bands generated were analyzed by using the Dice coefficient and the unweighted pair group method with averages (UPGMA) using a tolerance of $1 \%$.

\section{ERIC-PCR analysis}

Each isolate was also amplified by PCR using each of two primers for DNA repetitive sequences described by Versalovic: ERIC [Enterobacterial repetitive intergenic consensus; ERIC1 (5'ATGTAAGCTCCTGGGGATTCAC-3') and ERIC2 (5'-AAGTAAGTACTGGGGTGAGCG-3')]. The
PCR conditions were performed as described previously [18]. Amplicons were separated on (1.5\%) horizontal agarose gels, stained with ethidium bromide and visualized under UV light in the gel-doc system (BioRad, MuK nchen, Germany).

\section{PCR for spv region and plasmid preparation}

PCR was performed as described by Rubino [19], using oligonucleotide sequences corresponding to the $s p v R$ gene of the $S$. Typhimurium virulence plasmid (spvR3

5'-CCCCGGGAATTCGCTGCAT AAGGTCAGAAGG-3' and spvR5- 5'CCCCGGGATCCATGGATTTCTTGATTAATAAA -3') that amplify a fragment of $890 \mathrm{bp}$. Amplification products were separated on (1.2\%) horizontal agarose gels, stained with ethidium bromide and visualized under UV light in the gel-doc system (BioRad, MuK nchen, Germany).

Plasmid DNA was prepared by using a rapid procedure [20] in those strains that were $s p v R$ positive by the PCR assay. Plasmid sizes were determined using Escherichia coli V517 plasmids as standards [4].

\section{PCR for inv region}

PCR was performed as described [21] by using oligonucleotide sequences corresponding to the INV (invasion gene) invA1 (5'TGCCTACAAGCATGAAATGG-3') and invA2 (5'AAACTGGACCACGGTGACAA-3') that amplify a fragment of $457 \mathrm{bp}$. Amplification products were separated on $(1.5 \%)$ horizontal agarose gels, stained 
Table 2. Relationship between antibiotvpes and plasmid profiles of Salmonella Enteritidis strains

\begin{tabular}{|c|c|c|c|c|}
\hline Pattern & $\begin{array}{l}\text { Number of } \\
\text { isolates forSource } \\
\text { each patterns }\end{array}$ & Antibiotypes & \multicolumn{2}{|c|}{$\begin{array}{l}\text { Approx. plasmid } \\
\text { sizes }(K b)\end{array}$} \\
\hline $\mathrm{A}$ & $\mathrm{H}$ & GM & 7.2 & PT4 \\
\hline $\mathrm{B}$ & $\mathrm{H}$ & None & 7.2 & PT4 \\
\hline $\mathrm{C}$ & 1 & $\mathrm{~F}$ & 7.2 & PT4 \\
\hline $\mathrm{D}$ & 1 & $\mathrm{~F}$ & None & PT4 \\
\hline $\mathrm{E}$ & 3 & None & 7.2 & PT4 \\
\hline $\mathrm{F}$ & 1 & NAL & 7.2 & PT35 \\
\hline $\bar{G}$ & 1 & AMX, TIC, AMP & 7.2 & PT35 \\
\hline $\mathrm{H}$ & 1 & AMX, TIC, AMP & None & PT6a \\
\hline I & 1 & None & 7.2 & NT \\
\hline
\end{tabular}

with ethidium bromide and visualized under UV light in the gel-doc system (BioRad, MuK nchen, Germany).

\section{Results}

Isolation and subtyping

Fifteen strains belonging to Salmonella Enteritidis were isolated and characterized. Of the 15 strains, $(40 \%)$ and $(60 \%)$ were from food and human origin respectively.

\section{Drug resistance}

The strains tested for antimicrobial resistance showed high rates of sensitivity to the 14 drugs tested. Resistance to furan, ticarcillin, ampicillin and amoxicillin was shown in $13.34 \%$ of the strains. All strains were susceptible to ciprofloxacin, norfloxacin, ceftazidime, amikacin, amoxicillin-clavulanic acid, cefoxitin, cefotaxime, tobramycin and cephalothin. One human isolate was sensitive to all drugs tested (table 1).

\section{Phage typing and plasmid profile}

Among the $15 S$. Enteritidis strains analyzed, three types of phage profile were seen (Table 2). The human and food isolates fall into three distinct phage types, i.e., PT4, PT35, PT6a. One isolate was nontypeable. The PT4 represented the most prevalent lysotype with $40 \%$ for isolates of human origin and $33.34 \%$ for isolates of food origin. PT35 and PT6a occurred in $13.34 \%$ and $6.67 \%$ isolates respectively, and all originated from a food source. All human isolates belonged to PT4 phage type.

Table 2 summarizes the relation between plasmid profiles, antibiotypes and lysotypes patterns of $S$. Enteritidis strains isolated. The majority of strains share the same plasmid profile with one band of approximately $7.2 \mathrm{~K} \mathrm{bp}$ (data not shown). The two food strains that did not have any plasmids showed two different phage types. As Table 2 shows, some isolates had the same plasmid profile but different lysotypes and antibiotypes, as in case of patterns $\mathrm{E}$ and F. In contrast, others shared the same lysotypes and plasmid profiles but showed different antibiotypes, as in case of patterns A, B and C.

\section{PFGE patterns}

A total of four different profiles (arbitrarily designated as $X b 1$ to $X b 4)$, with 11 to 14 bands (Figure 1) in three clusters (Figure 2), were identified for the 15 strains. Most of the strains (66\%) belonged to PFGE pattern X1, which is the major subtype.

Figure 2 shows that among the three clusters (A to C), A was represented by twelve strains, B by two strains, and C by only one strain. PT4 strains were mostly identified in cluster A (profiles 1 and 3) and cluster B (profile 2), while PT35 were identified in cluster C (profile 4). Clusters A and B showed $(69.5 \%)$ similarity. Therefore, clusters A and B showed $(67.5 \%)$ similarity with cluster C. One PT35 strain showing a single PFGE pattern (profile 4) was resistant to nalidixic acid.

Six different patterns were observed for the 15 strains (Figure 3). Six isolates were grouped in one profile with five bands, and four isolates were grouped in one profile with six bands.

\section{Occurrence of invA gene spvR}

The invA and $s p v R$ products were approximately $472 \mathrm{bp}$ and $890 \mathrm{bp}$ respectively, as determined by gel agarose electrophoresis. The $s p v R$ gene was detected in only six strains of human source (Figure 4) that did not have the $90 \mathrm{~kb}$ plasmid, while invA gene was 


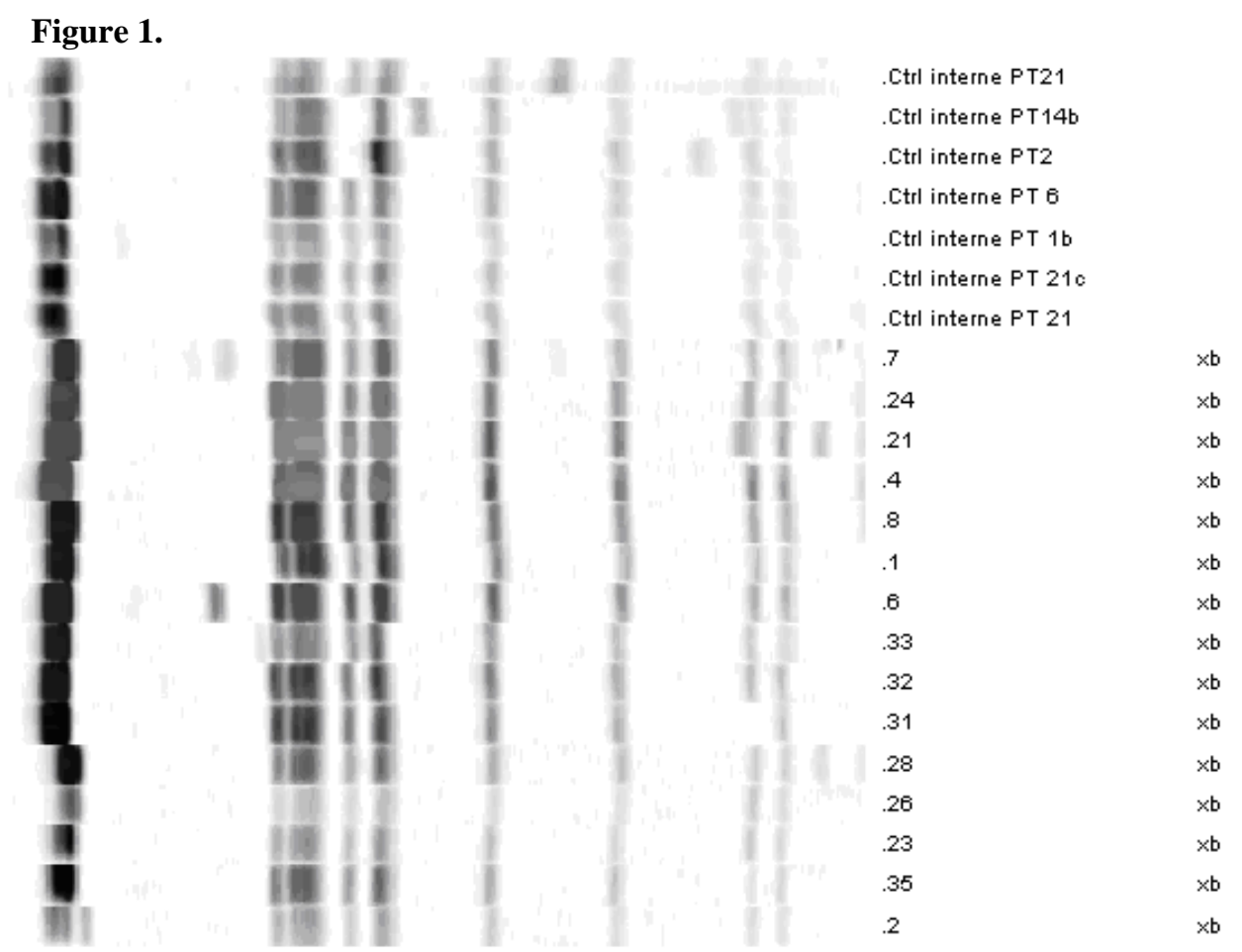

Pulsed field gel electrophoresis (PFGE) patterns for Xbal-digested genomic DNA of $S$. Enteritidis strains. Lanes 1 to 7: control marker for PFGE; strains 1-2-4-6-7-8 are human $S$. Enteritidis and 21-23-24-26-28-31-32-33-35 are food $S$. Enteritidis.

\section{Figure 2.}

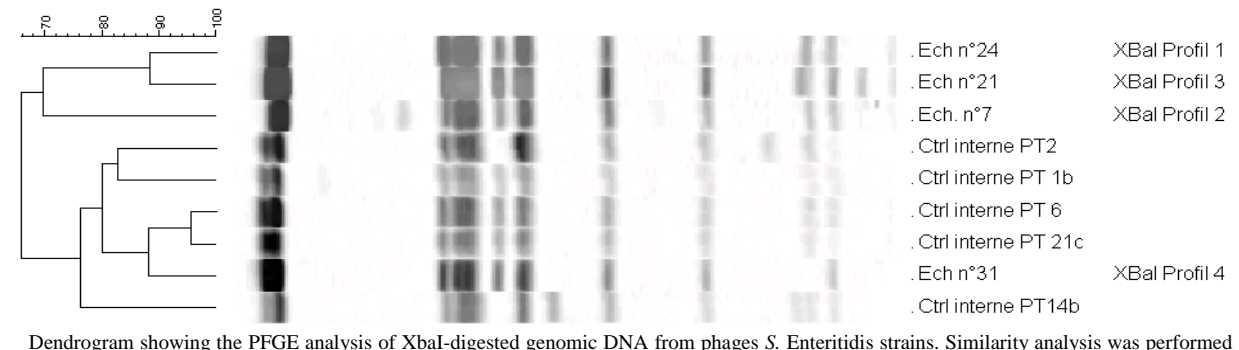

Dendrogram showing the PFGE analysis of XbaI-digested genomic DNA from phages $S$. Enteritidis strains. Similarity analysis was performed using the Dice coefficient, and clustering was by UPGMA.

detected in all the $S$. Enteritidis isolates (data not shown).

\section{Discussion}

Salmonellosis continues to be one of the major food-borne illnesses worldwide [22]. The predominant serotypes change over time and differ from one geographical area to another. All over the world, as well as in our country, the most often isolated serotype is $S$. Enteritidis [23], so detailed information about this pathogen using molecularbased methods is especially valuable.

The increase in antimicrobial resistance in Salmonella isolated from humans and animals in different parts of the world may indicate an epidemic spread of resistant or multi-resistant strains [24].

Recent studies indicate that most of the $S$. Enteritidis strains are susceptible to a wide range of antimicrobial agents [25]. In our study, high percentages of susceptibility were found for all 14 drugs. Compared to our findings, higher percentages of resistance to nalidixic acid $(31 \%)$ but lower resistance to gentamicin (1\%) were found by Cruchaga et al., [24] in $S$. Enteritidis isolates from humans in Spain 1998. Lower percentages of resistance for gentamicin (0-1\%) and nalidixic acid (2-4\%) were also found by Breuil et al. [26] in $S$. Enteritidis isolated from human and animal samples analyzed in 1994 and 1997 in France. 


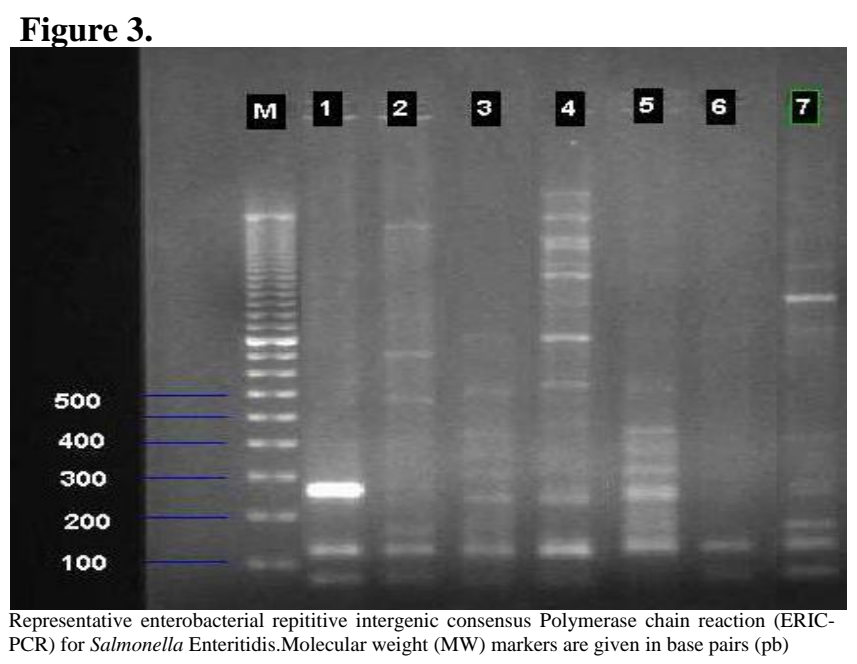

Phage typing, resistance typing and plasmid profile analysis are methods used in epidemiological studies of strains. Although phage typing has been used primarily for the epidemiological study of Salmonella, it is of little use in places where a small number of phage types predominates. Therefore, investigation of the antimicrobial susceptibilities, the characteristics of resistant strains, and the molecular epidemiology of the strains is more significant [27].

Studies from different parts of the world support the hypothesis that there is a clonal relationship between different $S$. Enteritidis phage types. PT4 is known to be the most common PT in England, Germany, Italy, and Japan [28]. PT4 remains the most frequent phage type isolated in Spain, followed by PT6 and PT1. PT8 is not as common in Spain as it is in Denmark or England [29]. In developing countries, as in Morocco, little information about Salmonella is available. These data are in accordance with our findings that PT4 was the predominant phage type.

The development of a phage typing scheme for $S$. Enteritidis has provided an invaluable means of differentiating strains of these serovars and proved particularly useful for epidemiological studies. However, phage typing becomes inadequate as a typing method when one particular type becomes dominant. As experienced in the current study, a similar observation was also reported by Powell [30].

Plasmid analysis was one of the first methods of molecular biology applied to the characterization of epidemic strains [31]. Nevertheless, in our study, the same plasmid profile was related to different antimicrobial resistance profiles and vice versa. However, the mobile character and appearance of a single plasmid in different strains, such as reported in the current study, might represent a limitation to the use of plasmid analysis in epidemiological investigations [17-30]. Our results, however, showed that there is no correlation between plasmid profiles and susceptibility data.

ERIC-PCR has been found useful for the typing of outbreak and sporadic Salmonella isolates. ERICPCR revealed that the 15 strains of $S$. Enteritidis isolated showed six different genotypic profiles. Kumao et al. concluded that ERIC-PCR is a useful technique for intraserotypic typing of Salmonella and recommends using it for first-line detection of strains from epidemics [32-33-34]. Similarly, ERIC-PCR showed a higher discriminatory power compared to the other techniques used in this study.

Genomic macrorestriction fragment length analysis by PFGE is now a widely used molecular tool for the subtyping of Salmonella spp. Only XbaI was used in this study, as it is a more discriminative and cheaper reagent, and it has been shown to be a useful restriction enzyme for Salmonella spp [35].

However, strains with different PFGE types may share the same phage type, and strains of different phage types may generate the same PFGE pattern. Pulsotype $\mathrm{X} 4$ is represented in this study by one member. It is possible, however, that many pulsotypes containing one member are due to the acquisition of mobile genetic elements, either temperate phages or plasmids. Furthermore, new sets of genes could be acquired by transduction, transposition, transformation or lysogenization with phage [36]. These data are in accordance with our findings. The study showed, interestingly, that isolates of the same PT produced different PFGE patterns, and that the strains of different phage types had the same PFGE pattern

\section{Figure 4.}

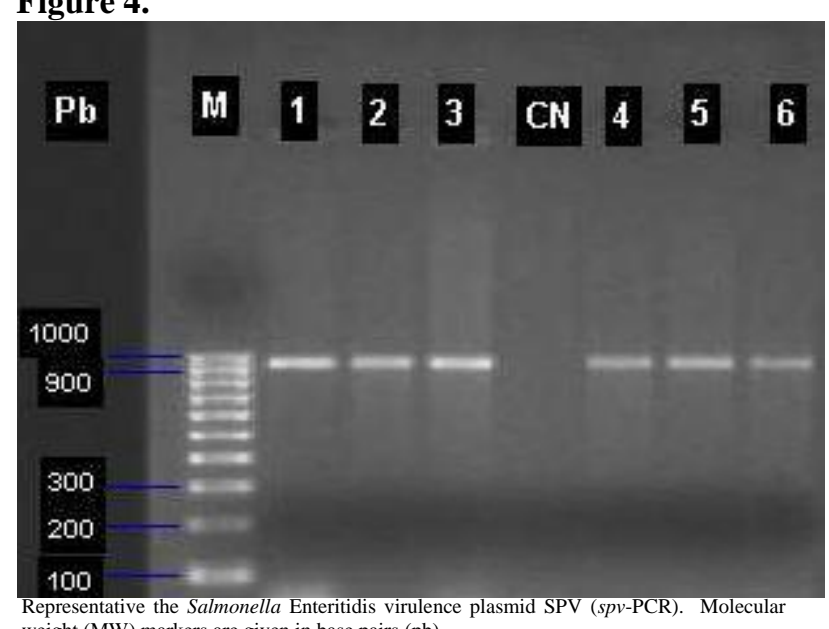

weight $(\mathrm{MW})$ markers are given in base pairs $(\mathrm{pb})$, 
For XbaI digested DNA, most of the strains belonged to the PFGE pattern X1 (10/15) and to the association X1/ PT4. Since the PFGE method has been shown to be highly discriminatory for subtyping of Salmonella spp including $S$. Enteritidis [41,42], strains with the same PFGE/phage type patterns, such as pattern X1/PT4, are likely to be closely related.

The majority of Salmonella virulence genes are clustered in chromosomal regions called Salmonella pathogenicity islands. The investigation using PCR for the presence of invA gene in this study demonstrated its presence in all $S$. Enteritidis isolates. Other studies have reported a similar result [19], which was expected since the invA is an invasion gene conserved among Salmonella serotypes. This finding was consistent with reports [43] that established the presence of invA gene in all Salmonella irrespective of serovar or source.

The gene harbored on a large virulence plasmid, including the virulence-associated locus termed $s p v$, might play a role in the multiplication of intracellular Salmonella. The $s p v \mathrm{R}$ region was detected in only six strains of isolates from humans that were not harboring the plasmid of $90 \mathrm{k}$. This observation suggests that the amplified genes were of chromosomal origin. In fact, the presence of the virulence gene $s p v R$ in Salmonella strains, which does not have plasmid DNA, suggests that the plasmid had integrated into the chromosome.

The gene $\operatorname{spvR}$ targeted in our study codes for a regulatory protein essential for the expression of the other $s p v$ genes; thus we can speculate that those isolates presenting this gene might be more capable of causing systemic infection [44]. The finding that $s p v R$ gene was associated with PT4 lysotype is of interest. This finding has important implications for comparative studies of the virulence within Salmonella serovars in Morocco.

In conclusion, to our knowledge, this is the first study on molecular characterization of $S$. Enteritidis from food and human samples. We observed that antibiotyping and phage typing remain valuable for use in the investigation of $S$. Enteritidis in Morocco. In addition, ERIC-PCR typing seems to be more discriminatory and well adapted to situations in which a rapid comparison of bacterial strains is needed.

\section{Acknowledgments}

This work was supported by grants from the Pasteur Institute of Morocco in Tangier. We express our gratitude to Dr. Ali Madini, Dr. Sarir Majdi, Dr. Touba Rajae, Dr. Said Bouda, Dr. Naima, Dr. Mohammed Hamdane, and Dr Mohammed Akad for their valuable help in completing this study. Thanks also go to Dr. Noredine Dersi and Fatna Bourjilat from the Pasteur Institute of Morocco in Casablanca. PFGE and phage typing were performed with the help of the Pasteur Institute in Bruxelles and the Reference Laboratory of Salmonellae and shigellae of Belgium.

\section{References}

1. Abasht B, Kaiser M, Lamont S (2008) Toll-like receptor gene expression in cecum and spleen of advanced intercross line chicks infected with Salmonella enterica serovar Enteritidis. Veterinary Immunology and Immunopathology 123: 314323.

2. Mahe A, Bougeard S, Huneau-Salau A, Bouquin S, Petetin I, Rouxel S, Lalande F, Beloeil P, Rose N (2008) Bayesian estimation of flock-level sensitivity of detection of Salmonella spp., Enteritidis and Typhimurium according to the sampling procedure in French laying-hen houses. Preventive Veterinary Medicine 84: 11-26.

3. Hilton AC, Penn C (1998) Restriction enzyme analysis of randomly amplified polymorphic DNA amplicons of Salmonella enterica ser. enteritidis PT4 and Typhimurium DT104. Journal of Microbiology 27: 158-162.

4. Michael GB, Cardoso M, Schwarz S (2006) Molecular analysis of Salmonella enterica subsp. Enterica serovar Agona isolated from slaughter pigs. Vet Microbiol 112: 4352.

5. Harbottle H, White D, McDermott P, Walker R, Zhao S (2006) Comparison of multilocus sequence typing, pulsedfield gel electrophoresis, and antimicrobial susceptibility typing for characterization of Salmonella enterica serotype Newport isolates. J Clin Microbiol 44: 2449-2457.

6. Gebreyes WA, Atelier C, Thakur S (2006) Molecular epidemiology and diversity of Salmonella serovar Typhimurium in pigs using phenotypic and genotypic approaches. Epidemiol Infect 134: 187-198.

7. Threlfall EJ, Hampton M, Rowe B (1994) Use of plasmid profile typing for surveillance of Salmonella enteritidis phage type 4 from humans, poultry and eggs. Epidemiol Infect 112: 25-31.

8. Ventura M, Meylan V, Zink R (2003) Identification and tracing of Bifidobacterium species by use of enterobacterial repetitive intergenic consensus sequences. Appl Environ Microbiol 69: 4296-4301.

9. Boyd EF, Hartl D (1998) Salmonella virulence plasmid: Modular acquisation of the $s p v$ virulence region by an Fplasmid in Salmonella enterica subspecies I and insertion into the chromosome of subspecies II, IIIa, IV and VII isolates. Genetics 149: 1184-1190.

10. Bessa MC, Michael GB, Canu N, Canal CW, Cardoso M, Rabsch W, Rubino S (2007) Phenotypic and genetic characterization of Salmonella enterica subsp. enterica serovar Typhimurium isolated from pigs in Rio Grande do Sul Brazil. Research in Veterinary Science 83: 302-310.

11. Benouda A, Zouhdi M, Alaoui M (1997) Epidémiologie des Salmonella non typhoidiques. Revue Marocaine de BiologieInfectiologie 3: 59-62.

12. Mhand RA, Brahimi N, Moustaoui N, El Mdaghri N, Amarouch H, Grimont F, Bingen E, Benbachir M (1999) 
Characterization of Extended-Spectrum $\beta$-LactamaseProducing Salmonella typhimurium by Phenotypic and Genotypic Typing Methods. Journal of Clinical Microbiology 37: 3769-3773.

13. Alial F, Boushiha A, Jouadi Z, Adnane F, Abid A (2004) Forty-one pediatric cases of non-typhoidal salmonellosis. Médecine et maladies infectieuses 34: 206-209.

14. Gascon J, Vargas M, Schellenberg D, Urassa H, Casals C, Vila. J (2000) Diarrhea in children under 5 years of age from Ifakara, Tanzania: a case-control study. J Clin Microbial 38: 4459-62.

15. Popoff M and Minor L (1992) Antigenic formulas of the Salmonella serovars, 7 ed., Institut Pasteur, Paris.

16. Anderson ES, Ward L, Saxe M (1977) Bacteriophage-typing designations of Salmonella typhimurium. J Hyg London 78: 297-300.

17. Schwarz S and Liebisch B (1994) Pulsed-field gel electrophoretic identification of Salmonella enterica serovar Typhimurium live vaccine strain Zoosaloral H. Lett Appl Microbiol 19: 469-472.

18. Versalovic J, Koeuth T, Lupski J (1991) Distribution of classic virulence factors among Salmonella spp. FEMS Immun Med Microbial 44: 251-259.

19. Dias de Oliveira S, Rodenbusch C, Michael GB, Cardoso MIR, Canal CW, Brandelli A (2003) Detection of virulence genes in Salmonella enteritidis isolated from different sources. J Braz Microbiol 34: 123-124.

20. Van der Walt ML, Maré L, Bezuidenhout M, Barnard A, Nieuwoudt B (1998) Rapid procedure for isolation and detection of Salmonella plasmids. Biotechnology Techniques 12: 769-772.

21. Stone G, Oberst R, Hays M, Chengappa M (1994) Detection of Salmonella serovars from clinical samples by enrichment broth cultivation-PCR procedure Journal of Clinical Microbiology 32: 1742-1749.

22. Gatto AJ, Peters TM, Green J, Fisher ST, Gill ON, O'Brien SJ, Maguire C, Berghold C, Lederer I, Gerner-Smidt P, Torpdahl M, Siitonen A, Lukinmaa S, Tschäpe H, Prager R, Luzzi I, Dionisi AM, Van der Zwaluw WK, Heck M, Coia J, Brown D, Usera M, Echeita A, Threllfall EJ (2006) Distribution of molecular subtypes within Salmonella enterica serotype Enteritidis phage type 4 and $S$. Typhimurium definitive phage type 104 in nine European countries, 2000-2004: results of an international multi-centre study. Epidemiol Infect 134: 729-36.

23. Zerrin A, Martin D, Cigdem B, Sukufe D, Threlfall E (2007) Molecular characterization of Salmonella Typhimurium and Salmonella Enteritidis by plasmid analysis and pulsed-field gel electrophoresis. International Journal of Antimicrobial Agents 30: 541-545.

24. Cruchaga S and Echfita M (2001) Antimicrobial resistance in salmonellae from humans, food and animals in Spain in 1998. Journal of Antimicrobial Chemotherapy 47: 315-321.

25. Kiessling S, Ofos J (2002) Antimicrobial resistance of foodrelated Salmonella isolates, 1999-2000. Journal of Food Protection 65: 603-608.

26. Breuil J, Brisabois A, Casin I, Armand L, Frémy S, Collatz E (2000) Antibiotic resistance in salmonellae isolated from humans and animals in France: comparative data from 1994 and 1997. Journal of Antimicrobial Chemotherapy 46: 965971.
27. Ang-Kuçuker M, Tolun V, Helmuth R, Rabsch W, Susever S, Ang O (2000) Phage type antibiotic susceptibilities and plasmid profiles of Salmonella typhimurium and Salmonella enteritidis strains isolated in Istanbul, Turkey. Clin Microbiol Infect 6: 593-599.

28. Sumalee B, Aroon B, Srirat P (1998) Epidemiological analysis of Salmonella enteritidis isolates from humans and broiler chickens in Thailand by phage typing and PulsedField Gel Electrophoresis. Journal of Clinical Microbiology 36: 971-974.

29. Usera MA, Aladuenfa A, Dýez R, Fuente M., Echeita A (2000) Analisis de las cepas de Salmonella sp aisladas de muestras clýnicas de origen humano en Espana (1996). Veterinary Microbiology 75: 155-165.

30. Powell NG, Threlfall E, Rowe B (1994) Subdivision of Salmonella enteritidis PT4 by pulsed-field gel electrophoresis Potential for epidemiological surveillance. FEMS 119: 193198.

31. Ktari S, Mahjoubi F, Hammami A (2006) Application de marqueurs génotypiques dans l'investigation de deux épidémies d'infections nosocomiales à Salmonella livingstone dans le CHU de Sfax, Tunisie. Pathologie et biologie 54: 331-336.

32. Versalovic J, Koeuth T, Lupski J (1991) Distribution of repetitive DNA sequences in eubacteria and application to fingerprinting of bacterial genomes. Nucleic Acids Res 19: 6823-31.

33. Merino LA, Ronconi MC, Navia MM, Ruiz J, Sierra JM, Cech NB, Lodeiro NS, Vila J (2003) Analysis of the clonal relationship among clinical isolates of Salmonella enterica serovar infantis by different typing methods. Rev Inst Med trop S. Paulo 45: 119-123.

34. Kumao T, Ba-Thein W, Hayashi H (2002) Molecular subtyping methods for detection of Salmonella enterica serovar oranienburg outbreaks. J Clin Microbiol 40: 2057-61.

35. .Stevens A, Kerouanton A, Marault M, Millemann Y, Brisabois A, Cavin JF, Dufour B (2008) Epidemiological analysis of Salmonella enterica from beef sampled in the slaughterhouse and retailers in Dakar (Senegal) using pulsedfield gel electrophoresis and antibiotic susceptibility testing. Journal of food microbiology 123: 191-197.

36. Brussow H, Canchaya C, Hardt W (2004) Phages and the evolution of bacterial pathogens: from genomic rearrangements to lysogenic conversion. Microbiology and Molecular Biology Reviews 68: 560-602.

37. Thong KL, Ngeow Y, Altwegg M, Navaratnam P, Pang T (1995) Molecular analysis of Salmonella Enteritidis by pulsed-field gel electrophoresis and ribotyping. Journal of Clinical Microbiology 33: 1070-1074.

38. Laconcha I, López-Molina N, Rementeria A, Audicana A, Perales I, Garaizar J (1998) Phage typing combined with pulsed-field gel electrophoresis and random amplified polymorphic DNA increases discrimination in the epidemiological analysis of Salmonella Enteritidis strains. International Journal of Food Microbiology 40: 27-34.

39. Fernandez J, Fica A, Ebensperger G, Calfullan H, Prat S, Fernandez A, Alexandre M, Heitmann I, (2003) Analysis of molecular epidemiology of Chilean Salmonella enterica serotype Enteritidis isolates by pulsed-field gel electrophoresis and bacteriophage typing. Journal of Clinical Microbiology 41: 1617-1622.

40. Jen-Chieh P, Tsai-Hsin C, Reiner H, Andreas S, Beatriz G, Hau-Yang T (2007) A pulsed field gel electrophoresis 
(PFGE) study that suggests a major world-wide clone of Salmonella enterica serovar Enteritidis. International Journal of Food Microbiology 116: 305-312.

41. Ridley AM, Threlfall E, Rowe B (1998) Genotypic characterization of Salmonella Enteritidis phage types by plasmid analysis ribotyping and pulsedfield gel electrophoresis. Journal of Clinical Microbiology 36: 231423121.

42. Tsen H, Hu H, Lin J, Huang C, Wang T (2001) Analysis of Salmonella Typhimurium isolates from food-poisoning cases by molecular subtyping. Food Microbiology 17: 143-152.

\section{Corresponding author}

Mohammed Abid

Service de Recherche

Laboratoire de Biologie Moléculaire

Institut Pasteur Du Maroc

1 rue al kortobi, Plateau Marchane, 90000

Tanger, Maroc

Phone: 21239932299, Fax : 21239932299

Email: mohammed.abid@pasteur.ma

Conflict of interest: No conflict of interest is declared.
43. Abouzeed YM (2000) Characterization of Salmonella isolates from beef cattle, broiler chickens and human sources on Prince Edward Island. Comparative Immunology, Microbiology and Infectious Diseases 23: 253-266.

44. Chishih C and Cheng-Hsun C (2006) Evolution of the virulence plasmids of non-typhoid Salmonella and its association with antimicrobial resistance. Microbes and Infection 8: 1931-1936. 